\title{
Drift algae: a contribution to near-shore habitat complexity in the pelagic environment and an attractant for fish
}

\author{
Michael J. Kingsford
}

School of Biological Sciences A08, University of Sydney, NSW 2006, Australia

\begin{abstract}
Drifting macrophytic algae increased habitat complexity in coastal waters of California, USA, especially in convergence zones. Algae are large and abundant structures, especially drift Macrocystis pyrifera ( 0.2 to $20 \mathrm{~m}$ long), and have been ignored in historical models of the pelagic environment. Drift plants redistribute small fish and invertebrates, and their movement (by wind and oceanographic features) can provide insight to the movements of meroplankton. The drift of whole $M$. pyrifera plants is also relevant to understanding the demography of kelp forests, whilst the droguelike qualities of plants can be used to study oceanographic features. The pelagic environment, therefore, is characterised by a hierarchy of structures $(0.05 \mathrm{~mm}$ to $>10 \mathrm{~m}$, marine snow to drift algae) and plankton, of different sizes.
\end{abstract}

KEY WORDS: Drift algae - Macrocytis pyrifera $\cdot$ Fish $\cdot$ Pelagic environment

Historically, the pelagic environment has been viewed as a uniform environment characterised by a hierarchy of plankton of different sizes, from microbes and tiny plants to large scyphomedusae (Fenchel 1988). Recent research has identified important structures or aggregates, coined 'marine snow', that typically range in size from $50 \mu \mathrm{m}$ to $10 \mathrm{~cm}$ (Silver et al. 1978, Barham 1979, Alldredge \& Silver 1988). The discovery of marine snow and aggregates of plant cells (Alldredge \& Silver 1982) has altered our understanding of the trophodynamics, primary production and nutrient recycling of pelagic environments as well as the transport of biotic material from the photic zone to the benthos (Alldredge \& Silver 1988). In this paper I describe abundant large structures and increased habitat complexitys.in coastal waters of California, USA, primarily composed of drifting macrophytic algae Macrocystis pyrifera. Fish and invertebrates are attracted to drifting objects (e.g. Hunter \& Mitchell 1967, Mitchell \& Hunter 1970, Dooley 1972). With the exception of the Sargasso Sea (Dooley 1972), drifting macroalgae have been largely ignored as a significant structural component of pelagic habitats and there are few data on the abundance of floating drift algae on large (tens of kilometres) and small (tens of metres) spatial scales.

Materials and methods. I studied the large-scale distribution patterns of drift algae near to and away from land off the coast of Santa Barbara, California (Fig. 1). Clumps of algae were counted from a small airplane and the weight of clumps was estimated. This was based on experience I had from weighing algae collected in the small-scale component of the study. Counts were made on 3 occasions (Time 1: 21 September 1992; Time 2: 30 November 1992; Time 3: 15 December 1992) at an altitude of $100 \mathrm{~m}$ (airspeed 120 to $144 \mathrm{~km} \mathrm{~h}^{-1}$ ). Algal clumps from the size of single laminae could be observed at this altitude. Counts were done along 2 transects $(\sim 40 \mathrm{~km}$ long) and at 5 locations, separated by 6 to $7 \mathrm{~km}$, within each transect (Fig. 1). Algae were counted in 5 replicate transects at each location. Transect length was $960 \mathrm{~m}$, determined by LORAN electronic position finder, and width estimated at $100 \mathrm{~m}$ by triangulation (based on viewing height to $45^{\circ}$ from horizontal); transect size was $926 \times$ $100=92600 \mathrm{~m}^{2}$; data are expressed as number or weight per 10 ha.

The small-scale distribution patterns of drift algae were studied in San Pedro Channel, Catalina Island, off Los Angeles, California. The position of individual clumps of algae was plotted on a map of the study area from a small boat. Position was determined by compass bearing and proximity to rocks. The wet weight of clumps was measured using a spring balance. An understanding of the movements of drift algae will elucidate the importance of drift algae for the dispersal of associated organisms and the influence it has on recruitment to reefs. Movements of algae were examined experimentally on 3 occasions (2, 3 and 4 September 1992) by releasing algae and recording the time it 


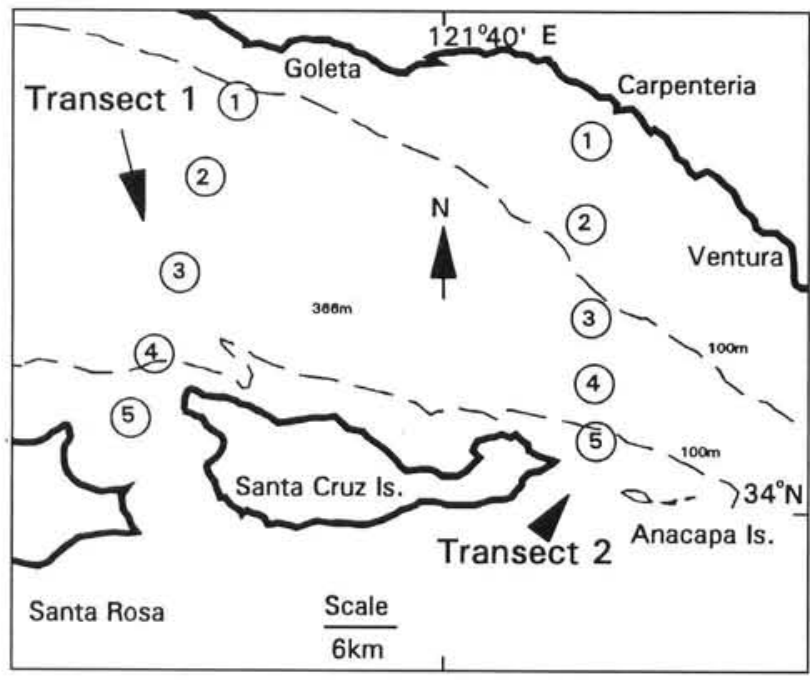

NUMBER OF CLUMPS
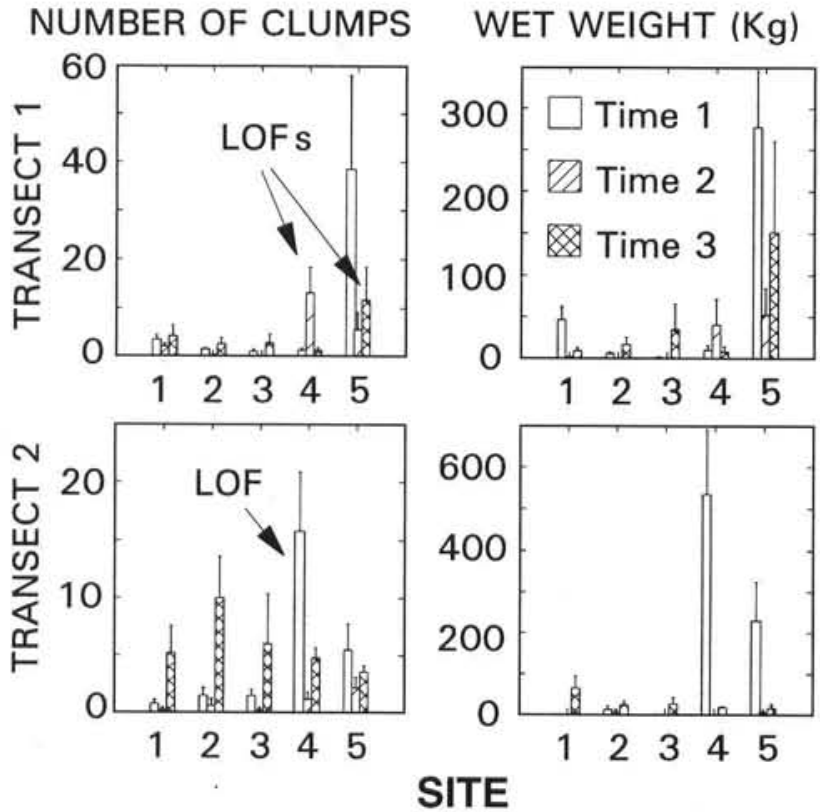

Fig. 1. Southern Californian Bight, USA, showing the location of sites sampled using an airplane along 2 transects extending from Goleta and Carpenteria towards Santa Cruz Island. The $100 \mathrm{~m}$ isobath is given. Abundances of drifting algae are presented as number of clumps and weight $(\mathrm{kg})$ for transects 1 and $2 ; n=5$ replicates within each site ( 1 to 5 ), unit area per replicate $=10$ ha mean $\pm 1 \mathrm{SE}$; LOF: Linear Oceanographic

Feature (e.g. frontal convergence sensu Kingsford 1990)

took to drift $50 \mathrm{~m}$ downwind. Clumps of algae $(2 \mathrm{~kg})$ were placed $50 \mathrm{~m}$ (measured with a tape that floated behind the boat) upwind of a tethered float perpendicular to the long axis of the shore on 2 occasions (Times $1 \& 2$ ) in 216 to $306 \mathrm{~m} \mathrm{~min}^{-1}$ winds. On the third occasion (Time 3) algae were released in 93 to $154 \mathrm{~m} \mathrm{~min}^{-1}$ winds and surface waves ( 25 to $35 \mathrm{~cm}$, trough to crest) running perpendicular to the wind; $\mathrm{n}=5$ clumps on each occasion. Wind direction was determined by compass. Wind speed and the size of surface waves was estimated by eye. The orientation of Macrocystis pyrifera in an adjacent kelp forest suggested it was not subjected to strong longshore currents at the time of sampling.

A $15 \times 3 \mathrm{~m}$ plankton purse seine net $(0.28 \mathrm{~mm}$ mesh) was used to seine fish around drift algae. The design of the net was modified from that of Kingsford \& Choat (1985). Open water controls were taken on some dates. Visual observations of fish associated with kelp and number of holdfasts on clumps were taken, while snorkelling, on plants ( $\mathrm{n}=20$ plants) in Santa Barbara Channel. I also attempted to document the movements of these plants by tagging them with $0.5 \times 1 \mathrm{~m}$ sheets of orange plastic, to the west of Santa Cruz Island; an aerial search was made the following day, and the position of plants was recorded with LORAN. Distance moved was calculated as the shortest distance from the release point to the final position.

Results and discussion. Drift algae (mostly Macrocystis pyrifera) were found near to and away from land in aerial surveys over the Santa Barbara Channel to Santa Cruz Island (Fig. 1). Large numbers of clumps and high biomasses of algae were found at some sites (e.g. mean weight $>150 \mathrm{~kg}$ per $10 \mathrm{ha}$ ). Proximity to land and potential 'source kelp forests' was not a good predictor of abundance of drifting kelp. Although drifting algae were often most abundant within $10 \mathrm{~km}$ of Santa Cruz (Sites $4 \&$ 5, both transects) this was not always the case. Rank abundance and weight of algae at each site varied among observations, probably due to the movements of the algae by currents, wind and a variable supply of plants from kelp forests. Algae were at times concentrated in a front located within $4.3 \mathrm{~km}$ of Santa Cruz Island [Fig. 1; this front was also observed from a boat (14 December 1992) and may be a topographic shear front located at the shelf slope]. High numbers and biomass of drift algae were consistently found at the western end of Santa Cruz (Transect 1, Site 5) and appeared to be due to oceanographic features that facilitated the retention of algae in this area. Hence, the presence of these oceanographic features are remotely apparent when delimited by algae. Although general patterns of oceanography are described for the southern Californian Shelf (e.g. Winant 1983), current patterns are complex (Browne 1993) and small-scale circulations $(<10 \mathrm{~km})$ in the vicinity of the Channel Islands are poorly known. Persistent aggregations of algae should provide greater focus for oceanographic and biological investigations. The distribution and behaviour of zooplankters, particularly small fish, will be influenced in retention areas and convergences by the presence of abundant large structures (i.e. $M$. pyrifera). Highest densities of kelp in 
single transects reached 110 clumps per 10 ha and $104 \mathrm{~kg} \mathrm{ha}^{-1}$, at distances of $4 \mathrm{~km}$ or more from land. This illustrates how habitat complexity can be increased greatly by drift algae in localised areas. The rate of detachment of plants from kelp beds and the subsequent input of drift to coastal waters will vary according to the seasonality of storms, particularly during unusually large storms (Dayton et al. 1992) such as those that occur during El Niño events (Tegner \& Dayton 1991).

Drift algae were also abundant within an $1.4 \times$ $0.8 \mathrm{~km}$ area, 1 to $2 \mathrm{~km}$ from Catalina Island ( 250 to $400 \mathrm{~kg}$ within the mapped area, Times 1 \& 2, Fig. 2),
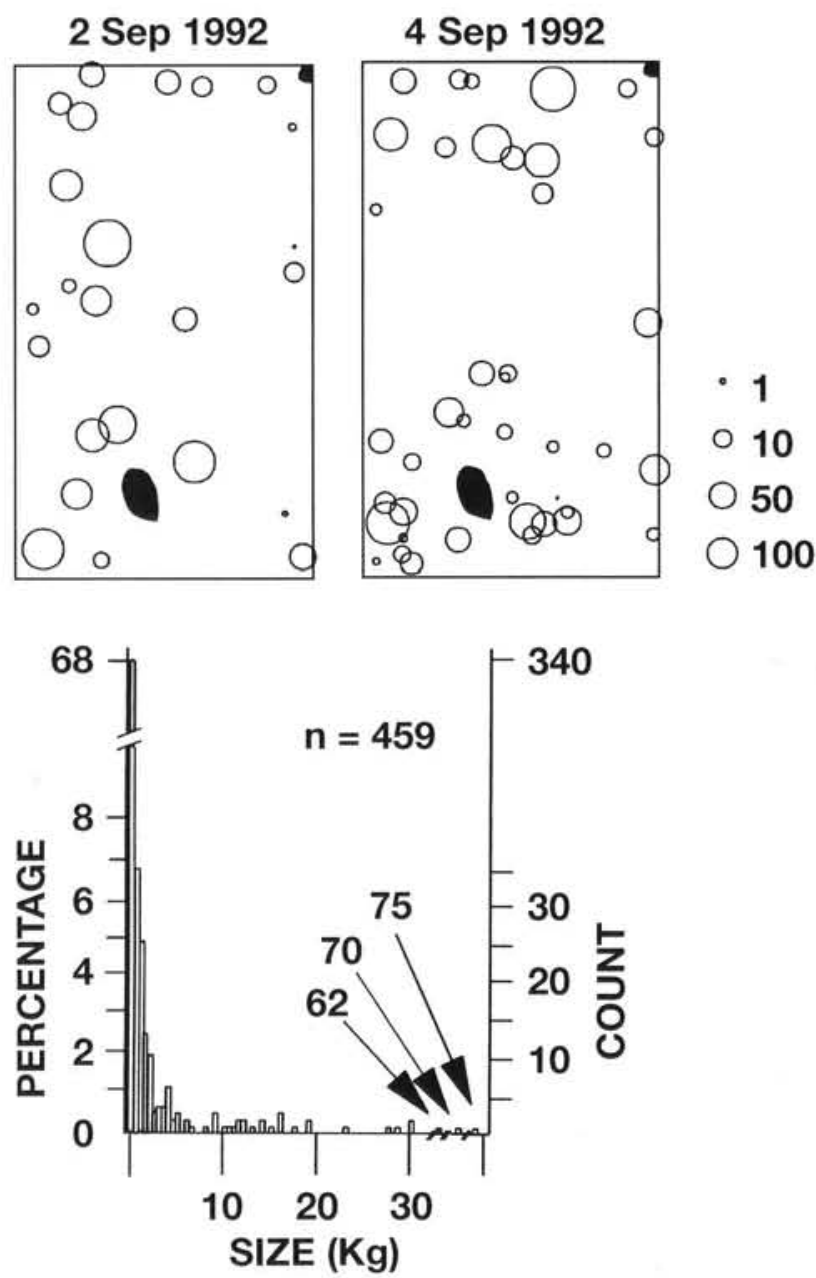

Fig. 2. Small-scale distribution patterns of drift algae within a $1.4 \times 0.8 \mathrm{~km}$ area in San Pedro Channel, Catalina Island, off Los Angeles, California, USA. Filled-in areas: Ship Rock (upper) and Bird Rock (lower). Symbol sizes for bubble plots are $\ln (x+1)$-transformations of the wet weight of algae $(\mathrm{kg})$; bubbles often represented more than 1 clump of drift in a small area $(\sim 10 \times 10 \mathrm{~m})$. Size frequency of algal clumps in $0.5 \mathrm{~kg}$ size classes. Note broken axes: weight of large clumps indicated with arrows. Rank abundance of algal types by weight: Macrocystis pyrifera $(97.5 \%)$, Egregia menziesii $(2 \%)$, Cystoseira spp. (0.49\%) and Pelvetia spp. $(0.001 \%)$ and clearly constituted increased habitat complexity of coastal waters. Mapping of clumps revealed that algae were patchily distributed throughout the study area, and that the spatial patterns changed between observations. Clumps ranged in size from $20 \mathrm{~g}$ (single frond) to $75 \mathrm{~kg}$ (whole plants) and averaged $1.7 \mathrm{~kg}$. All of these plants were within $1 \mathrm{~km}$ of kelp forests. This raises 2 points: (1) drift kelp increased the complexity of pelagic habitats within $1 \mathrm{~km}$ of kelp forests, and (2) although nearby kelp forests may be the source of some local drift, many clumps undoubtedly came from further afield, their movements influenced by wind and currents.

Experimental algal clumps (1 to $2 \mathrm{~kg}$ ) moved downwind at a rate of 3.3 to $5.4 \mathrm{~m} \mathrm{~min}^{-1}$ (216 to $309 \mathrm{~m} \mathrm{~min}^{-1}$ winds, Times 1 \& 2) and onshore winds generally caused the accumulation of natural drift near shore (pers. obs.). Hence, larvae of fish (e.g. Paralabrax clathratus, Chromis punctipinnis and Sebastes spp.; Table 1) that colonise algae drifting in coastal waters may be advected onshore by wind as well as by oceanographic features such as internal waves (e.g. Kingsford \& Choat 1986) and coastal currents (e.g. Winant 1983). Thus, the accumulation of algae nearshore may indicate an important recruitment event (e.g. Kingsford 1992), as transported early life-history stages settle into nearshore habitats. In low winds (93 to $154 \mathrm{~m} \mathrm{~min}^{-1}$ ) on one occasion, algae were transported downwind at $2(\mathrm{SE}=0.15) \mathrm{m} \mathrm{min}^{-1}$. Surface waves that were propagating perpendicular to the wind transported algae at $1.7(\mathrm{SE}=0.1) \mathrm{m} \mathrm{min}^{-1}$. Hence, surface waves may also be important for transport (Broche \& Forget 1992). Algae can drift considerable distances. I only observed 2 tagged clumps out of 20 after $24 \mathrm{~h}$, in which time they had moved a minimum of 10 to $12 \mathrm{~km}$. One plant was observed twice on the day of sampling and had moved $0.8 \mathrm{~km}$ in $2 \mathrm{~h}$.

Many algal clumps extended well below the surface of the water column because the heavy holdfasts were still attached. Some clumps had algae that hung down to depths of $1 \mathrm{~m}$ or more (maximum of $9 \mathrm{~m}$ ). Those drifting within 4 to $10 \mathrm{~km}$ of Santa Cruz Island had a mean of 3.1 holdfasts per clump ( $\mathrm{n}=20$ clumps, 8 to $230 \mathrm{~kg}$ ). Large plants act more like current-indicating drogues than small clumps because they are less prone to transport by light winds $\left(<460 \mathrm{~m} \mathrm{~min}^{-1}\right.$; pers. obs. $)$. Because coastal waters off southern California are subject to prolonged periods of winds less than $460 \mathrm{~m}$ $\min ^{-1}$, the drogue-like properties of algal clumps will reveal coastal retention areas, mainstream currents (Harrold \& Lisin 1989) and surface convergences such as internal waves (Kingsford \& Choat 1986) and Langmuir circulations (Faller \& Woodcock 1964).

Drifting macrophytes contribute to habitat complexity in surface waters. Perceptions of the pelagic 
Table 1. Fish associated with drift algae off the coast of southern California (see also Hunter \& Mitchell 1967, Mitchell \& Hunter 1970, Boehlert 1977). Fish were collected using a plankton mesh purse seine net (Kingsford \& Choat 1985). Values are the mean (SE in parentheses). \% occ.: percentage occurrence; size ranges are total length. Open water seines ( $\mathrm{n}=3$ seines) did not capture any of the species below on 4 July 1991 or 5 September 1992. Developmental stages (terminology according to Leis \& Rennis 1983) are J: juvenile; P: postflexion larva; PR: preflexion larva

\begin{tabular}{|c|c|c|c|c|}
\hline $\begin{array}{l}\text { Location \& date } \\
\text { Species (stage) }\end{array}$ & $\begin{array}{l}\text { Number } \\
\text { per clump }\end{array}$ & $\begin{array}{l}\text { Number } \\
\text { per kg }\end{array}$ & $\%$ occ. & $\begin{array}{c}\text { Size } \\
\text { range }(\mathrm{mm})\end{array}$ \\
\hline \multicolumn{5}{|c|}{5.6 to $7.4 \mathrm{~km}$ off Goleta ( $\mathrm{n}=6$ clumps, 0.25 to $14.5 \mathrm{~kg}$ ), 4 July 1991} \\
\hline Anoplopoma fimbria $(\mathrm{J})$ & $42(33)$ & $5.4(4)$ & 66 & $80-100$ \\
\hline Sebastes serriceps $(\mathrm{J})$ & $1.7(0.9)$ & $0.9(0.09)$ & 50 & $19-40$ \\
\hline Sebastes diploproa $(\mathrm{J})$ & $3.1(1.6)$ & $0.3(0.12)$ & 66 & $14-25.5$ \\
\hline Sebastes sp. (J) & $0.5(0.3)$ & $0.05(0.04)$ & 33 & $12-17.5$ \\
\hline Scorpaenichthys marmoratus $(\mathrm{J})$ & $0.2(0.2)$ & $0.01(0.01)$ & 15 & 38.7 \\
\hline Atherinidae (PR, P) & $0.2(0.2)$ & $0.01(0.01)$ & 15 & 18 \\
\hline Clinidae $(\mathrm{P})$ & $1.8(0.6)$ & $1.7(1.3)$ & 83 & $11-21.5$ \\
\hline Sygnathidae $(\mathrm{J})$ & $0.8(0.5)$ & $0.08(0.05)$ & 33 & $140-170$ \\
\hline Cottidae (PR) & $0.2(0.2)$ & $0.01(0.01)$ & 15 & 7.4 \\
\hline Unknown & $0.7(0.3)$ & $0.8(0.6)$ & 50 & $8.7-12$ \\
\hline \multicolumn{5}{|c|}{ San Pedro Channel, Catalina Is. $(\mathrm{n}=6$ clumps, 0.82 to $12.5 \mathrm{~kg}$ ), 3 September 1992} \\
\hline Medialuna californiensis $(\mathrm{J})$ & $16(9)$ & $13(8)$ & 66 & $32-44$ \\
\hline Chromis punctipinnis $(\mathrm{J})$ & $6(4.5)$ & $1.7(0.7)$ & 83 & $10-23$ \\
\hline Paralabrax clathratus $(\mathrm{P}, \mathrm{J})$ & $3.8(2.7)$ & $1(0.4)$ & 66 & $7.8-19$ \\
\hline Seriola lalandi $(\mathrm{J})$ & $0.3(0.2)$ & $0.3(0.2)$ & 33 & $33-64$ \\
\hline Unknown preflexion & $0.2(0.2)$ & $0.2(0.2)$ & 15 & 4 \\
\hline \multicolumn{5}{|c|}{ San Pedro Channel, Catalina Is. ( $\mathrm{n}=6$ clumps, 1 to $6 \mathrm{~kg}$ ), 5 September 1992} \\
\hline Chromis punctipinnis $(\mathrm{P}, \mathrm{J})$ & $2.5(2)$ & $0.8(0.7)$ & 33 & $11-22$ \\
\hline Paralabrax clathratus $(\mathrm{P}, \mathrm{J})$ & $3.8(0.8)$ & $1.3(0.2)$ & 100 & $8.7-18.1$ \\
\hline Sardinops sargax $(\mathrm{J})$ & $0.2(0.2)$ & $0.05(0.05)$ & 15 & 85 \\
\hline \multicolumn{5}{|c|}{1.9 to $9.3 \mathrm{~km}$ north off Santa Cruz Is. ( $\mathrm{n}=20$ clumps, 8 to $230 \mathrm{~kg}$ ), 14 December $1992^{\mathrm{a}}$} \\
\hline Medialuna californiensis $(\mathrm{J})$ & $11(4)$ & $0.2(0.08)$ & 45 & $70-130$ \\
\hline Chromis punctipinnis $(\mathrm{J})$ & $4.5(3.2)$ & $0.1(0.08)$ & 10 & $8-25$ \\
\hline Sebastes serriceps $(\mathrm{J})$ & $0.2(0.2)$ & 0.005 & 5 & $30-40$ \\
\hline
\end{tabular}

environment, therefore, should include a hierarchy of natural structures as well as plankters (Fenchel 1988), ranging from small aggregates and plant cells to large clumps of drift algae (especially laminariales and fucales) and other flotsam (Kingsford 1993). Although drift algae may represent a relatively small percentage cover of the ocean surface (estimated at $\leq 2 \%$ of the sea surface in transects where individual clumps in aerial surveys were estimated to average $3 \times 3 \mathrm{~m}$ ), this would give little indication of their importance in surface waters. Algae hang down and by moving through the water effectively 'fish' a volume that is much greater than their surface area would suggest. Aerial photography or video transects are potential methods for monitoring changes in the abundance of drift algae, but ground verification is required.

Drift algae provide a substratum that may be utilised by the early life-history stages of invertebrates (e.g. Highsmith 1985) and fish (e.g. Mitchell \& Hunter 1970, Kingsford \& Choat 1985). Abundant drift algae facilitate the redistribution of organisms in the pelagic environment and may influence the survivorship of species which depend upon drift algae for shelter and food.
The distribution and movement of algae will influence that of associated larvae. Studies of drift algae may lead to insights into the processes affecting the recruitment of the associated presettlement larvae and juveniles, e.g. do quantities of drift affect the magnitude of recruitment on small $(<1 \mathrm{~km})$ and large $(>10 \mathrm{~km})$ spatial scales? Invertebrates and fish that brood or bear live young may have increased dispersal by rafting on drift algae (e.g. Highsmith 1985, Kingsford 1992). Others (e.g. juvenile Medialuna californiensis, Table 1) may treat drift algae as a nursery habitat and the presettlement or 'larval phase' of some fish may be extended.

Due to the drogue-like properties of large macrophytes, oceanographic questions can be addressed as well. Habitat complexity can be greatly increased by drifting algae in convergences and retention areas.

Drift algae can also contribute to the dispersal of algal propagules. Algal spores may normally travel short distances $(<10 \mathrm{~m})$, but dispersal of spores increases during storms (Reed et al. 1988). Drift macrophytes that still have sporangia on the holdfast may have an important role in the dispersal of spores (Dayton 1985) at times. 
Drift algae which lose their floats sink, and like marine snow (Alldredge \& Silver 1988) may provide an important input to the benthos within tens of kilometres from the mainland (Harrold \& Lisin 1989). Drifting algae probably lose their floats after 7 to $10 \mathrm{~d}$ (Harrold \& Lisin 1989). If persistent oceanographic features concentrate the drift, then the benthos beneath the features may receive a higher input of carbon, accordingly drift algae that sinks may influence benthic assemblages. Other drifting algae may sink into reef environments (Dayton et al. 1992) or be washed up surf beaches as 'wrack'. With the exception of Harrold \& Lisin's (1989) work where kelp was tracked from kelp forests and up to $50 \mathrm{~km}$ from Monterey Peninsula, the fate of individual plants and the frequency of deposition in different environments is poorly known.

Drifting macrophytes are often abundant, constitute important structures and increase habitat complexity in the surface waters off California, and probably other parts of world where laminarian and fucoid algae with floats are abundant (Schiel \& Foster 1986). With the exception of the Sargasso Sea, drift algae should be most abundant in coastal waters. The presence of abundant large algae in pelagic environments contrasts with historical views that emphasise microscopic algae (i.e. phytoplankton). Contemporary views of the pelagic environment should include a hierarchy of structures from marine snow to drifting macrophytes.

Acknowledgements. I thank S. Holbrook, R. Schmitt and O. Hoegh-Guldberg for constructive criticism on the manuscript, and M. Atkinson and Brian Jenerson who helped in the field. Thanks also to the Australian Research Council for funds and Sally Holbrook and Russ Schmitt for logistical support at UCSB during a memorable sabbatical. I dedicate this paper to the memory of Dr Naja Vørs and the contribution she made to our understanding of the pelagic environment.

\section{LITERATURE CITED}

Alldredge, A., Silver, M. W. (1982). Abundance and production rates of floating diatom mates (Rhizolenia castranei and $R$. imbricata var. shrubsolei) in the Eastern Pacific Ocean. Mar. Biol. 66: 83-88

Alldredge, A. L., Silver, M. W. (1988). Characteristics, dynamics and significance of marine snow. Prog. Oceanogr. 20: $41-82$

Barham, E. G. (1979). Giant larvacean houses: observations from deep submersibles. Science 205: 1129-1131

Boehlert, G. W. (1977). Timing of the surface-to-benthic migration in juvenile rockfish, Sebastes diploproa, off southern California. Fish. Bull. U.S. 75: 887-890

Broche, P., Forget, P. (1992). Has the influence of surface waves on wind stress to be accounted for in modelling coastal circulation. Estuar. coast. Shelf Sci. 35: 347-351
Browne, D. R. (1993). Understanding the oceanic circulation in and around the Santa Barbara Channel. Proc. 8th Annual Information Transfer Meeting, MMS 93-0058, 95-108. U.S. Dept of Interior, Washington, DC

Dayton, P. K. (1985). Ecology of kelp communities. A. Rev. Ecol. Syst. 16: 215-245

Dayton, P. K., Tegner, M. J., Parnell, P. E., Edwards, P. B. (1992). Temporal and spatial patterns of disturbance and recovery in a kelp forest community. Ecol. Monogr. 62: 421-445

Dooley, J. (1972). Fishes associated with the pelagic - Sargassum complex, with discussion of the Sargassum community. Contrib. mar. Sci. 16: 1-32

Faller, A. J., Woodcock, A. H. (1964). The spacing of windrows of Sargassum in the ocean. J. mar. Res. 22: 22-29

Fenchel, T. (1988). Marine plankton and food chains. A. Rev. Ecol. Syst. 19: 19-38

Harrold, C., Lisin, S. (1989). Radiotracking rafts of giant kelp: local production and regional transport. J. exp. mar. Biol. Ecol. 130: 237-251

Highsmith, R. C. (1985). Floating and algal rafting as potential dispersal mechanisms in brooding invertebrates. Mar. Ecol. Prog. Ser. 25: 169-179

Hunter, J. R., Mitchell, C. T. (1967). Association of fishes with flotsam in the offshore waters of Central America. Fish. Bull. U.S. 66: 13-29

Kingsford, M. J. (1990). Linear oceanographic features: a focus for research on recruitment processes. Aust. J. Ecol. 15: $391-401$

Kingsford, M. J. (1992). Drift algae and small fish in coastal waters of northeastern New Zealand. Mar. Ecol. Prog. Ser. 80: 41-55

Kingsford, M. J. (1993). Biotic and abiotic structure in the pelagic environment: importance to small fish. Bull. mar. Sci. 53: 393-415

Kingsford, M. J., Choat, J. H. (1985). The fauna associated with drift algae captured with a plankton-mesh purseseine net. Limnol. Oceanogr. 30: 618-630

Kingsford, M. J., Choat, J. H. (1986). Influence of surface slicks on the distribution and onshore movements of small fish. Mar. Biol. 91: 161-171

Leis, J., Rennis, D. S. (1983). The larvae of Indo-Pacific coral reef fishes. New South Wales University Press, Sydney

Mitchell, C., Hunter, J. R. (1970). Fishes associated with drifting kelp, Macrocytis pyrifera, off the coast of southern California and northern Baja California. Calif. Dept. Fish. Game Bull. 56: 288-297

Reed, D. C., Laur, D. R., Ebeling, A. W. (1988). Variation in algal dispersal and recruitment: the importance of episodic events. Ecol. Monogr. 58; 937-948

Schiel, D. R., Foster, M. S. (1986). The structure of subtidal algal stands in temperate waters. A. Rev. Oceanogr. mar. Biol. 24: 265-307

Silver, M. W., Shanks, A. L., Trent, J. D. (1978). Marine snow: microplankton habitat and source of small-scale patchiness in pelagic populations. Science 201: 371-373

Tegner, M. J., Dayton, P. K. (1991). Sea urchins, El Niños, and the long term stability of southern California kelp forest communities. Mar. Ecol. Prog. Ser. 77: 49-63

Winant, C. D. (1983). Longshore coherence of currents on the Southern California Shelf during the summer. J. phys. Oceanogr. 13: 54-64 